\title{
Impact of Automated Teller Machine (ATM) Service Quality on Customer Satisfaction in the Nepalese Commercial Banks ${ }^{1}$
}

\author{
Chhemanand Joshi
}

\begin{abstract}
The aim of this study was to understand the impact of ATM service quality on the customer satisfaction in Nepalese banking sector. This study has used the primary data of customer satisfaction survey $(\mathrm{N}=60)$. The data was collected using a structured questionnaire designed to ascertain the satisfaction levels. Descriptive statistics analysis was used to explain the satisfaction level of respondents. Correlations and multiple linear regression analysis were used to test the hypothesis. The ATM services have positive impact on the customer satisfaction; if proper functioning is ensured by the banks, there will be significantly higher customer satisfaction. Availability of cash has highest impact on customer satisfaction. Next most influencing factor is location of ATM. The study has been carried out primarily in Dhangadhi, Kailali and hence cannot be generalized on all over Nepal. The banks can utilize the finding to improve the services of ATMs and can enhance the overall satisfaction of their customers. The paper has identified, availability of cash as the most influencing significant factor, which the banks may take care to enhance the customer satisfaction.
\end{abstract}

Keywords: Automated Teller Machine (ATM); Service quality, customer satisfaction; Nepalese commercial banks.

\section{Introduction}

The banking sector is considered as a fundamental backbone of economy for development. It simplifies the production of goods and services by providing loan/liquidity for development of new industries as well as cash deposit and withdrawn facilities. Technology has been significantly transforming the banking activities. So, banks have been using technology like Automated Teller Machines (ATMs), internet banking, and mobile banking to reduce cost and enhance efficiency, productivity, and customer convenience/satisfaction. In this context, the technological facilities provided by banks are required for the systematic study (Research) and sustainability of banking activities.

Customer satisfaction is important for business success. Satisfaction depends on product and service quality. Banking sector provides various services to customers for higher customer satisfaction. In present competitive environment, customer satisfaction is an important element to win the competitors. Bank management should identify the service quality dimensions to satisfy their customers by research and development programs. The banking industry is highly competitive. Banks are not only competing among each other; but also with non-banking and financial institutions (Kaynak \& Kucukemiroglu, 1992). Customer satisfaction is predetermined by how the expectations of the customer are met (Kotler \& Keller, 2011). Customer satisfaction is directly connected to customers' needs. The degree to which these needs are fulfilled determines the enjoyment in the case of conformity or disappointment from discrepancy (Hill, Allen, \& Rachel, 2007). Consumer behavior is also regular researchable phenomena.

Service quality has been determined as an analytical factor of success for the firms through which they can formulate their competitive advantage. Many researchers have studied about service quality to find out its dimensions including tangibility, reliability, responsiveness, assurance and empathy (Parasuraman \& Berry, 1991). The service quality accompanies services of Internet banking to encourage the customers toward the usage of online banking services (Raza \& Hassan, 2015). The services of Internet banking, which should be offered necessarily, include ease of use, perceived usefulness, reliability, accessibility, security, privacy and responsiveness (Liao \& Cheung, 2008).

The dimension of tangibility is associated with the physical equipment, physical facilities, personnel and the materials which are related to communication. However, in the context of Internet banking, tangibility is usually related to the design of web sites, contents provided by the banks, installation of updated technologies and visually appealing physical facilities. Reliability basically refers to the capability of performing the promised services precisely as well as deliberately (Parsuraman

\footnotetext{
${ }^{1}$ Cite this article as: Joshi, C. (2019). Contemporary Research: An Interdisciplinary Academic Journal, vol. 3 (1): Chhemanand Joshi, Lecturer, Ghodaghodi Multiple Campus, Kailali, Nepal

Email: Joshichhema@gmail.com

Peer reviewed under the authority of CRAIAJ, academic journal of Ghodaghodi Multiple Campus, Kailali, Nepal. (C) 2019 Contemporary Research: An Interdisciplinary Academic Journal
} 
Joshi, C. CRAIAJ (2019), vol. 3 (1): 7-18

et al., 1988, 1991). As far as internet banking is concerned, the dimension of reliability consists of providing relevant information to the users as well as timely and reliable services. The responsiveness is associated with the compliance of service providers to deliver help and instant services to the customers. This dimension consists of providing response to the customers regarding any of the queries related to their online bank accounts. The responsiveness dimension also includes convenience and easy accessibility of online banking services. The dimension of assurance is related to the information and courtesy of employees, as well as their competency to convey reliance and confidence. Assurance dimension is composed of reliable answers and consistent services, sustaining the privacy of account, as well as maintaining error-free records. Empathy refers to the provision of caring and providing peculiar attention to the customers on individual basis. This dimension is associated with providing the best interests to the customers, understanding their particular needs, providing convenient operating hours, and providing individual concentration to the customers.

\section{Statement of the problem}

In the present competitive banking environment, Nepalese banks are trying to provide more and more facilities to their customers. Technological service quality is improving to attract and retain the customers. ATM is a highly using technology in banking sector. Is ATM service really a success to satisfy the bank customers' needs? What is the condition of customer satisfaction on ATM banking? These types of questions are answered by research activity. Prior study in India shows the ATM services have positive impact on the customer satisfaction (singh, 2011). Nepalese banking sector also using ATM services. Customers are satisfied or not by the ATM services? This phenomenon is researchable in Nepal. For this study following research questions are extracted;

$>$ What is the relationship between ATM service Quality and customer satisfaction?

What is the impact of ATM service quality on customer satisfaction?

\section{Objectives of the study}

This study has been initiated with the main objective of determining relationship between ATM service quality and customer satisfaction. The specific objectives of this study are as follows:

$>$ To examine the relationship between dimensions of ATM service quality and customer satisfaction.

$>$ To analyze the impact of ATM service quality dimensions on customer satisfaction.

\section{Research hypothesis}

The ATM services have positive impact on the customer satisfaction but some characteristics have very high customer satisfaction whereas some characteristics have the lower customer satisfaction level (Singh, 2011). According to the evidence of prior studies, following hypotheses have been tested;

$\mathbf{H}_{1}$; Security and privacy of ATM have significant positive relation with customer satisfaction.

$\mathbf{H}_{2}$; Availability of cash has significant positive relation with customer satisfaction.

$\mathbf{H}_{3}$; Response to the query has significant positive relation with customer satisfaction.

$\mathbf{H}_{4}$; Time to process request has significant positive relation with customer satisfaction.

$\mathbf{H}_{5}$; Location of ATM has significant positive relation with customer satisfaction.

$\mathbf{H}_{6}$; Availability of networked (Shared) ATM has significant positive relation with customer satisfaction.

$\mathbf{H}_{7}$; Fees charge for using other bank's ATM has significant Negative relation with customer satisfaction. 
Joshi, C. CRAIAJ (2019), vol. 3 (1): 7-18

\section{Literature review}

There are many definitions of customer satisfaction based on different aspects; such as, Kotler and Keller (2009) defined "satisfaction can also be a person's feelings of pleasure or disappointment that results from comparing a product's perceived performance or outcome with their expectations". Sureshchander et al., (2002) expressed that "consumer's level of satisfaction is determined by his or her cumulative experience at the point of contact with the supplier". These two definitions examined the concept of customer satisfaction under the gap between pre-purchase and post-purchase or the gap between previous performance and current one.

Customer satisfaction determinants are likely to be different by the nature of businesses. Satisfied customers are also likely to tell others of their favorable experiences and thus engage in positive word-of-mouth advertising (File K.M., 1992). Strong linkages have been apparent between service quality dimensions and overall customer satisfaction (Anderson \& Sullivan, 1993). Customer satisfaction is widely recognized as a key influencing factor in the formation of consumers' future purchase intentions (Taylor \& Baker, 1994). Levesque and McDougall (1996) have conducted a study on factors of customer satisfaction in retail banking using the SERVQUAL instrument. Variables included in the research are relational performance, core performance, tangibility, competitive rates, enabling, future intentions and customer satisfaction. The results of the study show that the features related to service quality, which include relational (Buzzell \& Gale, 1997) (Fornell, Johnson, Anderson, Cha, \& Bryant, 1996) performance, features and core performance, exist in retail banking, and these have a strong influence on customer satisfaction. High-quality service and customer satisfaction often result in more repeat purchases and market share improvements (Buzzell \& Gale, 1997).

Lovelock (2000) identified the dimensions of ATM service quality such as secure and convenient location, adequate number of ATM, user-friendly system, and functionality of ATM. Joseph and Stone (2003), through focus group study in the USA, found that easy access to location, user-friendly ATM and security are important factors that influence majority of bank customers' perception of ATM service quality. Mcandrews (2003) identified that secure and convenient location, adequate number of ATM, user-friendly system and functionality of ATM play important role in customers' satisfaction. Singh, (2011) identified the variables as; location of ATM/proximity to your residence/office, availability of cash, time to process request, number of ATMs in locality, response to the query, availability of desired forms, availability of cheque drop boxes, queues at ATM/time required doing a transaction, printed statement of transaction, cash deposit facility, availability of networked (shared) ATMs and fee charged for using other bank's ATMs.

Service quality can contribute to customer satisfaction. However, Karim and Oyefolahan (2009) showed that service quality and customer satisfaction are though independent, but are closely related. An increase in one is likely to lead to an increase in another. These authors also mentioned that delivery of the service, physical dimensions, staff interaction with customers, and trustworthy processes and procedures positively affect the quality of services in any business. In another research conducted on a sample of 1000 retail banking customers and found that customer satisfaction plays the role of a mediator between service quality and customer loyalty (Caruana, 2013). Furthermore, it shows that all the service quality attributes are positively related to customer satisfaction and customer satisfaction is positively related to customer loyalty (Siddiqi, 2011).

There are two basic concepts at the bottom of customer satisfaction surveys: the expectations, which represent what customers expect from the service, and the perceptions, which represent what customer receive. Expectations are evaluated by the customers through the indication of a level of importance; perceptions, instead, are evaluated by a judgment of satisfaction. Customer satisfaction can be evaluated by collecting only customer perceptions, or through the comparison between expectations and perceptions (Parasuraman, Zeithaml, \& Berry, 1984)

\section{Modeling customer satisfaction}

Many researchers have observed that satisfaction is a sense of feeling which comes from a procedure of interpreting and judging what is received as a result of expectation as an inclusion of wishes and requirements coupled with the purchase and purchase choice (Bharwana, Bashir, \& Mohsin, 2013). Customer satisfaction plays a major role in customer loyalty, but it does not always guarantee customer loyalty. Therefore, the business should focus on enhancing customer perceptions of service quality, satisfaction, perceived value, and corporate image (Hua, Kandampully, \& Juwaheer, 2009). Customer satisfaction is an outcome of a matching between customers' expectation about the product (value and quality) itself and services they received from the businesses under the friendly surrounding business facilities and environment. 
Joshi, C. CRAIAJ (2019), vol. 3 (1): 7-18

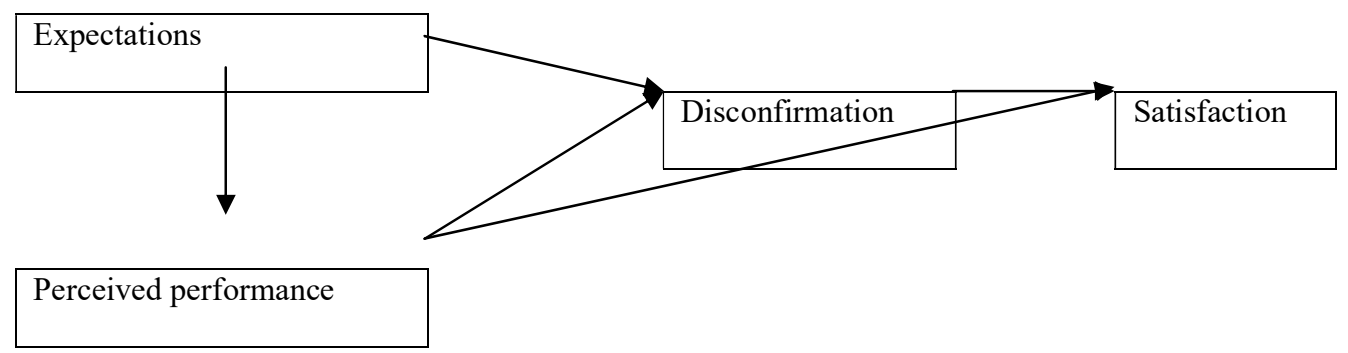

Figure 1: Customer satisfaction model (Expectation-confirmation theory)

Expectations-confirmation theory posits that expectations, coupled with perceived performance, lead to post-purchase satisfaction. This effect is mediated through positive or negative disconfirmation between expectations and performance. If a product outperforms expectations (positive disconfirmation) post-purchase satisfaction will result. If a product falls short of expectations (negative disconfirmation) the consumer is likely to be dissatisfied (Oliver, 1980).

Customer satisfaction is a latent variable; therefore most of studies have used the structural model to analyze it (Noyan \& Simsek, 2011; Martinelli \& Balboni, 2012). Structural models define how outcomes relate to preferences and to relevant factors in the economic environment, identifying mechanisms that determine outcomes (Low \& Meghir, 2017). But some of them have also used a regression model (Levesque \& McDougall, 1996) to analyze the customer satisfaction. This study has used the multiple regression models to determine the relations between dependent and independent variables.

\section{Research framework}

By reviewing previous studies, it has been proposed a research framework as follows to study the "Impact of ATM Service Quality on Customer Satisfaction".

\section{Independent variables $\quad \underline{\text { Dependent variable }}$}

\section{Security and privacy of ATM}

\section{Availability of cash}

Response to the query

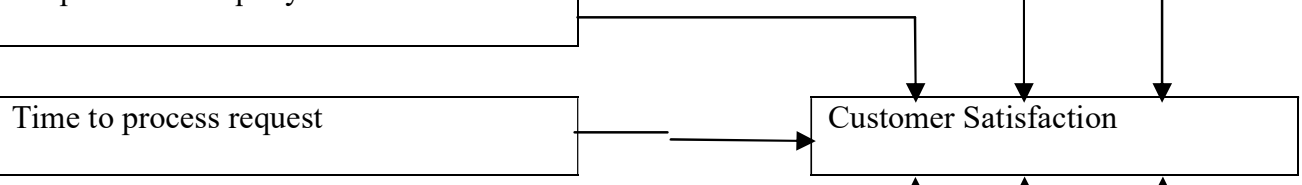

Location of ATM

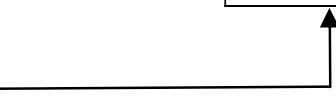

Availability of networked ATM

Fees charge for using other bank's ATM

Figure 2: Research Framework 


\section{Research methodology}

The study follows descriptive research design considering its aims of describing the relationship between various factors of ATM services and customer satisfaction. Descriptive research aims at accurately and systematically describing a population, situation or phenomenon. It can answer what, when, where, and how questions but not why questions.

The population of this study is all ATM users of four commercial banks; Everest Bank, Nabil bank, NICASIA Bank and Siddhartha Bank in Dhangadhi, kailali. Sample size is sixty (60) customers equally divided into four banks (15 from each bank).

Data were collected using convenience sampling method. Direct interview was taken at ATM centre with selected sixty (60) respondents by the researcher. Demographic characteristics and their experience about ATM service quality were collected through a structured questionnaire.

Descriptive analysis has used to explain the demographic characteristics and satisfaction level of respondents. Correlations and multiple linear regression analysis were used to test the hypothesis. The model to estimate the impact of service quality on customer satisfaction in parametric form was defined as follows:

$$
\mathrm{CS}=\alpha+\beta_{1} \mathrm{SP}+\beta_{2} \mathrm{AC}+\beta_{3} \mathrm{RQ}+\beta_{4} \mathrm{TPR}+\beta_{5} \mathrm{LOC}+\beta_{6} \mathrm{AN}+\beta_{7} \mathrm{FC}+\varepsilon \ldots
$$

Here, CS is customer satisfaction, $\alpha$ is constant, $\beta$ is slope coefficient, SP is security and privacy of ATM, AC is availability of cash, RQ is response to query, TPR is time to process request, LOC is location of ATM, AN is availability of networked ATM and FC is fees charge for using other bank's ATM. For testing reliability of questionnaire Cronbach's alpha was used. Normally, measurements with Cronbach's alpha higher than 0.7 is used. Some professionals, as a rule of thumb, require a reliability of 0.70 or higher with 0.60 as the lowest acceptable threshold. Data were summarized and analyzed by using the Statistical Program for Social Sciences, version 20 (SPSS 20).

\section{Data analysis}

\section{Reliability analysis}

Reliability analysis refers to the analysis of the instrument designed to collect the data for the research. It determines whether the scale consistently reflects the construct it is measuring or not. Cronbach, in 1951 introduced a common measure in reliability analysis which is known as Cronbach's alpha. It is an estimate of internal consistency associated with scores of every item.

Table 1 Reliability Statistics

\begin{tabular}{ll}
\hline Cronbach's Alpha & $\begin{array}{l}\text { N of } \\
\text { Items }\end{array}$ \\
\hline 0.809 & 7 \\
\hline
\end{tabular}

Table 2 Item Reliability Statistics

\begin{tabular}{|c|c|}
\hline Items & Cronbach's Alpha \\
\hline Security and privacy of ATM & 0.802 \\
\hline Availability of cash & 0.801 \\
\hline Response to the query & 0.772 \\
\hline Time required to do a transaction & 0.767 \\
\hline Location of ATM & 0.765 \\
\hline Availability of networked ATM & 0.808 \\
\hline $\begin{array}{l}\text { Overall satisfaction on service quality } \\
\text { of ATM }\end{array}$ & 0.764 \\
\hline
\end{tabular}


Joshi, C. CRAIAJ (2019), vol. 3 (1): 7-18

Table 1 and 2 show the reliability analysis or Cronbach's alpha. According to Table 1, construct reliability is 0.809 or higher than generally accepted value (score) of 0.7 . Table 2 shows item reliability. All the items have values of Cronbach's alpha higher than 0.7. So, it can be conclude that scale designed to measure dependent and independent variables has collected reliable data for the research. So, further analysis can be done. One variable, "Fee charge for using other bank's ATM" is measured in different scale with single construct so, reliability is not tested.

\section{Descriptive statistical analysis}

Descriptive statistics are used to describe the basic features of the data. They provide summary measures of the data. The summary statistics of all the variables in this study is presented as in the following table showed that 60 observations for each variable, the mean and standard deviation values are calculated.

Table 3 Customer satisfaction on service quality of ATM $(N=60)$

\begin{tabular}{llllll}
\hline Service quality & worst & Poor & Satisfactory & Good & Excellent \\
\hline Security and privacy of ATM & 0 & 2 & 9 & 25 & 24 \\
Availability of cash & 0 & 3 & 12 & 18 & 27 \\
Response to the query & 3 & 4 & 18 & 24 & 11 \\
Time required to do a transaction & 2 & 2 & 9 & 22 & 21 \\
Location of ATM & 4 & 5 & 8 & 28 & 20 \\
Availability of networked ATM & 0 & 1 & 11 & 29 & 14 \\
Overall satisfaction on ATM & 0 & 5 & 12 & & 29 \\
\hline
\end{tabular}

Table 3 displays the customers experience towards ATM service quality. Most of customers have ranked their satisfaction on availability of networked ATM and security and privacy as good (28 \& 25 respectively out of 60) and no one expressed as worst. Availability of cash has ranked as excellent by highest number of customers or 27 out of 60 . Response to the query, time required to do a transaction and location of ATM were ranked as good by majority of customers 24, 24 and 22 respectively. Overall satisfaction on service quality of ATM was ranked as good by 29 customers out of 60 and no one ranked as worst so, it can be conclude that most of customers are satisfied by ATM service quality.

Table 4 Descriptive Statistics analysis of mean and standard deviation

\begin{tabular}{lccc}
\hline Variables & $\mathrm{N}$ & Mean & Std. Deviation \\
\hline Security and privacy of ATM & 60 & 4.18 & 0.813 \\
Availability of cash & 60 & 4.15 & 0.917 \\
Response to the query & 60 & 3.6 & 1.028 \\
Time required to do a transaction & 60 & 4.07 & 0.989 \\
Location of ATM & 60 & 3.85 & 1.191 \\
Availability of networked ATM & 60 & 4.12 & 0.761 \\
Fee charge for using other bank's ATM & 60 & 2.7 & 0.889 \\
Overall satisfaction on ATM & 60 & 3.87 & 0.873 \\
\hline
\end{tabular}


Joshi, C. CRAIAJ (2019), vol. 3 (1): 7-18

Table 4 indicates that among the variables security and privacy has the highest mean value (4.18) and followed by availability of cash (4.15), availability of networked ATM (4.12) and time required doing a transaction (4.07) but fee charge for using other bank's ATM has lowest mean value. Therefore it can be concluded that respondents are most satisfied with security and privacy of ATM with mean and standard deviation of 4.18 and 0.813 respectively. Respondents are dissatisfied with the variable, fee charge for using other bank's ATM with mean 2.7 or less than 3 (satisfactory).

\section{Correlation analysis}

Pearson's correlation has computed to show the relation among the variables and presented in Table 4.6. The result indicates that, there is significant positive relation between security \& privacy and customer satisfaction $(r=.322, p<.05)$, availability of cash and customer satisfaction $(\mathrm{r}=.512, \mathrm{p}<.01)$, response to the query and customer satisfaction $(\mathrm{r}=.506, \mathrm{p}<.01)$, time required to do transaction and customer satisfaction $(\mathrm{r}=.501, \mathrm{p}<.01)$, Location of ATM and customer satisfaction $(\mathrm{r}=.535, \mathrm{p}$ $<.01)$ and Availability of networked ATM and customer satisfaction $(\mathrm{r}=.304, \mathrm{p}<.05)$. Fee charge for using other bank's ATM and customer satisfaction has insignificant negative relation $(r=-.009, p<.947)$. The findings of correlation further indicate that highest relation between location of ATM and customer satisfaction $(r=.535, \mathrm{p}<.01)$ than other variables.

Table 5: Correlations

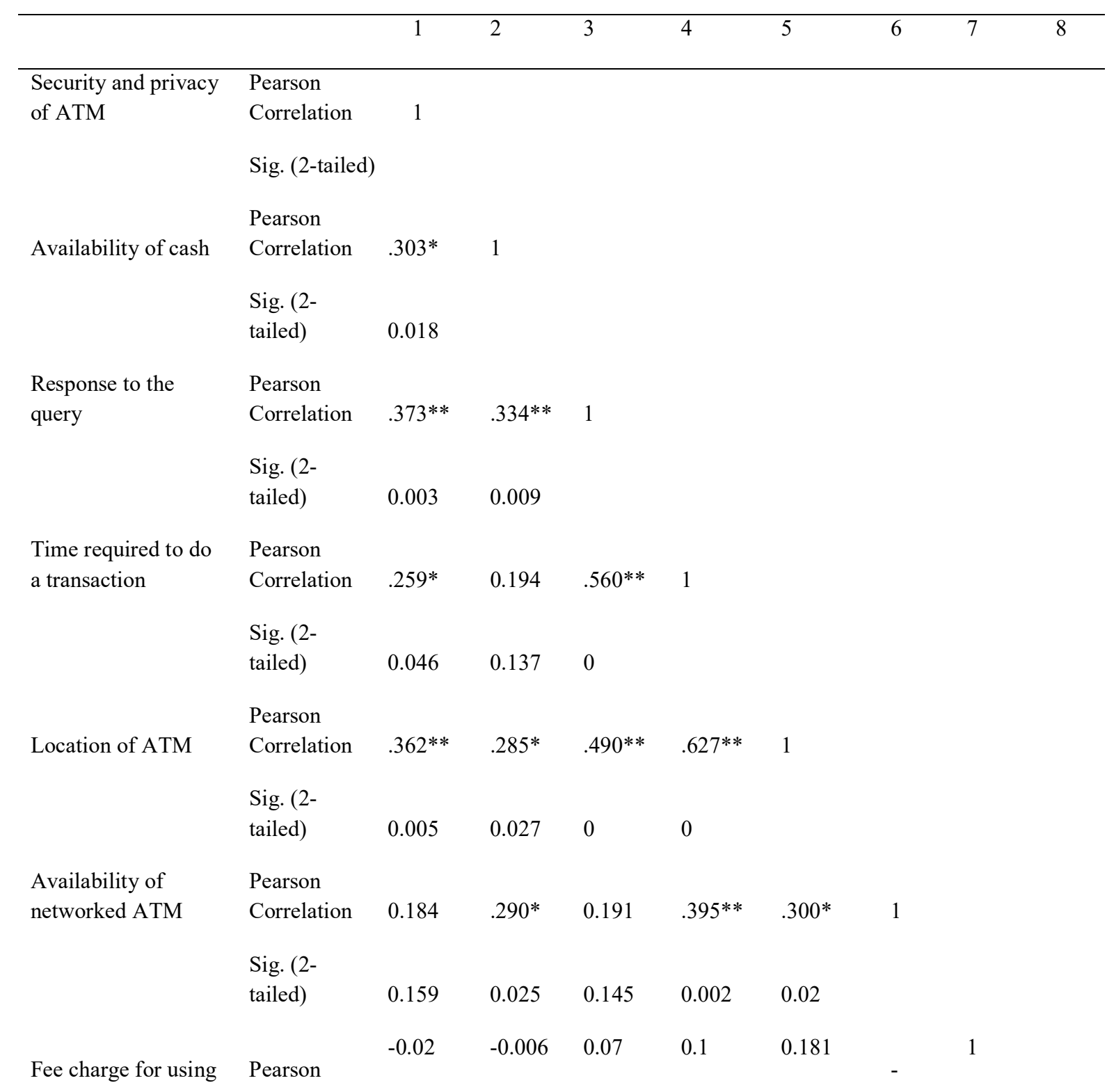


Joshi, C. CRAIAJ (2019), vol. 3 (1): 7-18

other bank's ATM Correlation

0.023

Sig. (2-

tailed)

0.901

$0.962 \quad 0.593$

0.446

0.166

0.864

Overall satisfaction on service quality of

$\begin{array}{lllllllll}\text { Correlation } & .322 * & .512 * * & .506 * * & .501 * * & .535 * * & .304 * & -0.009 & 1\end{array}$

Sig. (2-

tailed)

0.012

0

0

0

$0.018 \quad 0.947$

* Correlation is significant at the 0.05 level (2-tailed). ** Correlation is significant at the 0.01 level (2-tailed).

All the developed hypotheses are supported except hypothesis $\mathrm{H}_{7}$; fees charge for using other bank's ATM has significant negative relationship with customer satisfaction. It has insignificant negative relationship with customer satisfaction

$(\mathrm{r}=-.009, \mathrm{p}=.947>0.05)$

Multiple regression analysis

Multiple regression analysis has been used to investigate the relationship between dependent and independent variables. It also determines the impact of ATM service quality variables on customer satisfaction. The multiple regression equation/model of this study is built around two sets of variables, namely dependent variable (customer satisfaction) and independent variables (security \& privacy of ATM, cash availability, response to the query, time required to do a transaction, location of ATM, availability of networked ATM and fee charge for networked ATM). Multiple regression analysis is presented in given tables.

Table 6 Model Summary

\begin{tabular}{lllll}
\hline Model & R & R Square & Adjusted R Square & Std. Error of the Estimate \\
\hline 1 & $.702 \mathrm{a}$ & 0.493 & 0.425 & 0.662
\end{tabular}

a) Predictors: (Constant), Fee charge for using other bank's ATM, Availability of cash, Time required to do a transaction, Security and privacy of ATM, Availability of networked ATM, Response to the query, Location of ATM. b) Dependent Variable: Overall satisfaction on service quality of ATM

From Table 6, it can be seen that the R square value for the regression model showed $49.30 \%$ of the variation in the model can be predicted by independent variables or, predictors ( 0.493 is close to $0.5 \mathrm{so}$, it is satisfactory to proceed the data ahead). In other words the seven predictors; security \& privacy, availability of cash, response to the query, location of ATM, time required to doing a transaction, availability of networked ATM and fee charge for using other bank's ATM explained 49.3\% of the total variation of dependent variable customer satisfaction with adjusted R square of 0.425 .

Table 7 ANOVA Table

\begin{tabular}{lllllll}
\hline Model & & Sum of Squares & df & Mean Square & F & Sig. \\
\hline 1 & Regression & 22.172 & 7 & 3.167 & 7.236 & .000 \\
& Residual & 22.762 & 52 & 0.438 & & \\
& Total & 44.933 & 59 & & \\
\hline
\end{tabular}

a Dependent Variable: Overall satisfaction on service quality of ATM 
Joshi, C. CRAIAJ (2019), vol. 3 (1): 7-18

b Predictors: (Constant), Fee charge for using other bank's ATM, Availability of cash, Time required to do a transaction, Security and privacy of ATM, Availability of networked ATM, Response to the query, Location of ATM

Table 7 gives the ANOVA test on the overall significance of the model. ANOVA table of multiple regressions showed $\mathrm{F}(7,59)=7.236, \mathrm{p}<.000$, indicating at least one of predictors' slope coefficients is statistically significant.

Table 8 Coefficients

\begin{tabular}{|c|c|c|c|c|c|c|c|c|}
\hline \multirow[t]{2}{*}{ Model } & & \multicolumn{2}{|c|}{$\begin{array}{l}\text { Unstandardized } \\
\text { Coefficients }\end{array}$} & $\begin{array}{l}\text { Standardized } \\
\text { Coefficients }\end{array}$ & \multirow[t]{2}{*}{$\mathrm{t}$} & \multirow[t]{2}{*}{ Sig. } & \multicolumn{2}{|c|}{$\begin{array}{l}\text { Collinearity } \\
\text { Statistics }\end{array}$} \\
\hline & & $\mathrm{B}$ & $\begin{array}{l}\text { Std. } \\
\text { Error }\end{array}$ & Beta & & & Tolerance & VIF \\
\hline \multirow[t]{8}{*}{1} & (Constant) & 0.7 & 0.695 & & 1.008 & 0.318 & & \\
\hline & $\begin{array}{l}\text { Security and privacy } \\
\text { of ATM }\end{array}$ & 0.017 & 0.12 & 0.016 & 0.14 & 0.889 & 0.785 & 1.274 \\
\hline & Availability of cash & 0.323 & 0.106 & 0.34 & 3.061 & 0.003 & 0.79 & 1.265 \\
\hline & $\begin{array}{l}\text { Response to the } \\
\text { query }\end{array}$ & 0.14 & 0.11 & 0.165 & 1.278 & 0.207 & 0.582 & 1.717 \\
\hline & $\begin{array}{l}\text { Time required to do } \\
\text { a transaction }\end{array}$ & 0.163 & 0.127 & 0.185 & 1.286 & 0.204 & 0.471 & 2.124 \\
\hline & Location of ATM & 0.178 & 0.1 & 0.243 & 1.784 & 0.08 & 0.525 & 1.904 \\
\hline & $\begin{array}{l}\text { Availability of } \\
\text { networked ATM }\end{array}$ & 0.027 & 0.128 & 0.024 & 0.213 & 0.832 & 0.78 & 1.282 \\
\hline & $\begin{array}{l}\text { Fee charge for using } \\
\text { other bank's ATM }\end{array}$ & -0.079 & 0.099 & -0.08 & -0.791 & 0.432 & 0.953 & 1.049 \\
\hline
\end{tabular}

a Dependent Variable: Overall satisfaction on service quality of ATM

Table 8 shows the unstandardized and standardized beta coefficients. They predict a change in the independent variables (ATM service quality dimensions), would produce an effect on the dependent variable (customer satisfaction). According ANOVA table overall regression model is significant so, the model can be presented as;

$$
\mathrm{CS}=0.7+0.017 \mathrm{SP}+0.323 \mathrm{AC}+0.14 \mathrm{RQ}+0.163 \mathrm{TPR}+0.178 \mathrm{LOC}+0.027 \mathrm{AN}-0.079 \mathrm{FC}+\varepsilon \ldots
$$

Here, CS is customer satisfaction, $\alpha$ is constant, $\beta$ is slope coefficient, SP is security and privacy of ATM, AC is availability of cash, RQ is response to query, TPR is time to process request, LOC is location of ATM, AN is availability of networked ATM and FC is fees charge for using other bank's ATM.

Availability of cash has highest impact on customer satisfaction. Keeping other variables constant, if one unit change in cash availability, customer satisfaction will positively changed by 0.323 units. Next most influencing factor is location of ATM. It leads the changes in customer satisfaction by 0.178 positively.

The relatively small result of Variance Inflation Factor (VIF smaller than 10) shows that these independent variables are not closely related to each other so there is no Multicollinearity. The coefficients analysis shows the result of multiple regression analysis. Positive mark of regression coefficients show that components in the regression model above has positive relationship with customer satisfaction and negative mark of regression coefficients show the negative relationship with (dependent variable) customer satisfaction. 
Joshi, C. CRAIAJ (2019), vol. 3 (1): 7-18

In terms of each component, Availability of cash has a coefficient of 0.323 , with significant value $(p)=0.003$ or, $(p<0.05)$. Thus, Availability of cash has the most significant impact on customer satisfaction. Similarly, the coefficient of Security and privacy of ATM is 0.017 , Sig. $=0.889(\mathrm{p}>0.05)$. Because of that, Security and privacy of ATM has insignificant positive influence on customer satisfaction. Other remaining independent variables including; Response to the query 0.14 , Sig. $=0.207(\mathrm{p}>0.05)$, time required to doing a transaction 0.163 , Sig. $=0.204(\mathrm{p}>0.05)$, location of ATM 0.178, Sig. $=0.08$ $(p>0.05)$, availability of networked ATM 0.027 , Sig. $=0.832(p>0.05$ have greater than significant level 0.05 , so all these components are not significantly effect on customer satisfaction. It means that only one out of seven hypotheses $\mathrm{H}_{2}$; availability of cash has significant positive relation with customer satisfaction is accepted.

\section{Summary}

The banking sector is considered as a fundamental backbone of economy for development. Technology has been significantly transforming the banking activities. So, banks have been using technology like Automated Teller Machines (ATMs), internet banking, and mobile banking to reduce cost and enhance efficiency, productivity, and customer convenience/satisfaction. Customer satisfaction is important for business success. Satisfaction depends on product and service quality. Banking sector provides various services to customers for higher customer satisfaction. Service quality has been determined as an analytical factor of success for the firms through which the firms can formulate their competitive advantage, as well as enhance their competencies.

The analysis of this study showed that most of customers have ranked their satisfaction on security and privacy as good. Availability of cash has ranked as excellent by highest number of customers (27 0ut of 60). Response to the query, time required to do a transaction and location of ATM were ranked as good by majority of customers and overall satisfaction on service quality of ATM was ranked as good. Security and privacy has the highest mean value (4.18) and followed by availability of cash (4.15). Overall satisfaction on ATM is ranked by majority of customers (29 out of 60) as good. The correlation result indicates that there is significant positive relationship between ATM service quality variables and customer satisfaction except one variable 'fees charge for using other bank's ATM.' All developed hypotheses are supported except hypothesis $\mathrm{H}_{7}$; fees charge for using other bank's ATM has significant negative relationship with customer satisfaction. It has insignificant negative relationship with customer satisfaction. Multiple regressions result showed, availability of cash has highest impact on customer satisfaction. Next most influencing factor is location of ATM. In terms of each component, Availability of cash has a coefficient of 0.323 , with significant value $(p)=0.003$ or, $(p<0.05)$. Thus, Availability of cash has the most significant impact on customer satisfaction. It means that only one out of seven hypotheses $\mathrm{H}_{2}$; availability of cash has significant positive relation with customer satisfaction is accepted.

\section{Managerial implications and future research}

This study has determined the relationship between ATM service provided by Nepalese commercial banks and customer satisfaction in Dhangadhi, kailali, Nepal. The findings of the study will help the banking industry by showing how quality services offered by ATM service points are essential. The conclusions and recommendations of the study will be used for helping the banking industry in the identification of weaknesses in the use of ATM system, in modernized banking, for the improvement of their services. This study can also be significant for the future scholars who will pursue research in fields related to ATM service quality system and customer satisfaction. This research does not focus on the association between customer satisfaction and retention of customers. Future research may explore the relationship between these constructs. Association between different age group, gender and satisfaction also may be explored.

\section{Limitation of the study}

This study has been conducted in Dgangadhi sub-metropolitan city of Nepal, the findings of this study may not be generalized for the whole country. Only four bank's ATM users have been studied as sample. Variables were tested according to appropriateness in Nepalese context on 60 ATM users equally divided into four commercial banks. Only ATM service has been studied among internet banking services. It has covered seven service quality variables with small sample size.

\section{Conclusion}

The main objectives of this research were to examine the relationship between ATM service quality and customer satisfaction as well as to analyze the impact of ATM service quality on customer satisfaction. The findings of this research confirmed that 
Joshi, C. CRAIAJ (2019), vol. 3 (1): 7-18

ATM service quality have positive impact on the customer satisfaction. Some variables have very high customer satisfaction whereas some variables have the lower customer satisfaction level. The factors which have lower customer satisfaction level are the major concern area for the banks and there is need to pay more attention.

In Nepalese context location of ATM has higher relationship with customer satisfaction. Availability of cash has highest impact on customer satisfaction. Security \& privacy and fees charge for using other bank's ATM have less impact on customer satisfaction and which are the most significant factors have overall lower satisfaction level; these factors need further attention by the banks and there is scope for further improvement in the customer satisfaction levels. So the banks need to keep these factors in mind while designing the strategies to enhance the customer satisfaction. The rapid growth in use of ATMs in Nepal provides opportunities to the banks in innovative service for strategic advantage.

\section{Acknowledgements}

Ghodaghodi Multiple Campus Research Committee under the RMC Mini Research assistance to the faculty financially assisted this research in the fiscal year 2076-077. I sincerely acknowledge RMC's valuable support.

\section{References}

Anderson, E., \& Sullivan, M. (1993). Customer satisfaction, market share and profitability. Marketing Science, 12, 125-143.

Bharwana, T. K., Bashir, M., \& Mohsin, M. (2013). Impact of service quality on customers' satisfaction: A study from service sector especially private colleges of Faisalabad, Punjab, Pakistan. International Journal of Scientific and Research , 3 (5), 1-7.

Caruana, A. (2013). Service loyalty: The effects of service quality and the mediating role of customer satisfaction. European Journal of Marketing , 36 (7/8), 811-828.

File K.M., P. R. (1992). Positive word-of -mouth: Customer satisfaction and buyers behavior. International Journal of Marketing, 10 , 2529.

Fornell, C., Johnson, M. D., Anderson, E. W., Cha, J., \& Bryant, B. E. (1996). The American customer satisfaction index: Nature, purpose, and findings. Journal of Markting , 60, 7-16.

Hua, H.-H., Kandampully, J., \& Juwaheer, T. D. (2009). Relationships and impacts of service quality, perceived value,customer satisfaction, and image: An empirical study. The Service Industries Journal , 29 (2), 111-125.

Karim, N. S., \& Oyefolahan, I. O. (2009). Mobile phone appropriation: Exploring differences in terms of age, gender and occupation. The 6th International Conference on Information Technology and Applications , 276-281.

Kaynak, E., \& Kucukemiroglu, \&. O. (1992). Bank and product selection; Hong Kong. The international Journal of Bank Markrting, 10 (1), 3-17.

Kotler, P., \& Keller, \&. K. (2009; 2011). Marketing management. 14th Edition. Inc. Upper Saddle river.: Pearson Education.

Levesque, T., \& McDougall, G. H. (1996). Determinants of customer satisfaction in retail banking. International Journal of Bank Marketing $, 14(7), 12-20$.

Liao, Z., \& Cheung, M. (2008). Measuring customer satisfaction in internet banking: A core framework. Communications of the ACM, 51 (7) , 47-51.

Martinelli, E., \& Balboni, B. (2012). Retail service quality as a key activator of grocery store loyalty. The Service Industries Journal , 32 (14), 2233-2247.

Oliver, R. L. (1980). A Cognitive model of the antecedents and consequences of satisfaction decisions. Journal of Marketing Research, 17 (4), 460-469.

Parasuraman, A., Zeithaml, V. A., \& Berry, L. L. (1984). A conceptual model of service quality and its implications for future research. Journal of Marketing , 49 (4), 41-50.

Parasuraman, A., \& Berry, L. (1991). Refinement and reassessment of the SERVEQUAL scale. Journal of Retailing, 67 (4) , $420-450$. 
Joshi, C. CRAIAJ (2019), vol. 3 (1): 7-18

Raza, S., \& Hassan, A. (2015). Internet banking and customer satisfaction in Pakisthan. Qualitative Research in Financial Market, 7 (1), $24-$ 36.

Siddiqi, K. O. (2011). Interrelations between Service quality attributes, customer satisfaction and customer loyalty in the retail banking sector in Bangladesh. International Journal of Business and Management , 6 (3), 12-36.

Singh, J., \& Mishra, D. (1997). Understanding the structure of consumers' satisfaction evaluations of service delivery. Journal of the Academy of Marketing Science, 34 (5), 34-38.

Singh, s. (2011). Impact of ATM service quality on customer satisfaction. Financial Services Management, 5 (2), 177-196.

Taylor, S., \& Baker, T. (1994). An assessment of the relationship between service quality and customer satisfaction. Journal of Retailing, 2 , 163-178. 